YАK 347

ББК 67.404

DOI 10.22394/1682-2358-2017-2-60-64

A.G. Demieva, Candidate of Sciences (Law), Docent of the Civil Law Department, Kazan Federal University (email: ademieva@bk.ru)

\section{JUDICIAL PRACTICE: LAWMAKING OR LAW ENFORCEMENT?}

The problem of definition of the place of court practice in the system of sources of the Russian civil law is analyzed. Specifics of resolutions of the Supreme Court of the Russian Federation and the Constitutional Court of the Russian Federation are studied. The criterion by which it is necessary to delimit the concepts "judicial law enforcement" and "judicial lawmaking" is formulated.

Key words and word-combinations: court practice, source of law, lawmaking.
А.Г. АемиеЪа, кандидат юридиеских наук, дочент кафедри гражданского права Казанского (Приволжского) федерального университета (email: ademieva@bk.ru)

\section{СУАЕБНАЯ ПРАКТИКА: ПРАВОТВОРЧЕСТВО ИАИ ПРАВОПРИМЕНЕНИЕ?}

\footnotetext{
Аннотация. Рассматривается проблема определения места судебной практики в системе источников российского гражданского права. Раскрывается специфика постановлений Верховного Суда РФ и Конституционного Суда РФ. Сформулирован критерий, по которому следует разграничивать понятия «судебное правоприменение» и «судебное правотворчество».

Ключевые слова и словосочетания: судебная практика, источник права, правотворчество.
}

ппоры о том, следует $\Lambda и$ признавать судебную практику самостоятельным источником российского права, продолжаются десятилетиями. Научная полемика по Аанному вопросу сопутствует истории существования судебной системы России.

О судебной практике как имеющей второстепенное к законодательству значение писам К.П. Победоносцев [1, с. 454]. Г.Ф. Шершеневич указывац, что «правоведение только устанавцивает, какое общее правило выражается в ряде конкретных решений» [2, с. 27]. «Закон и суд не Аве вражлебные силы, а два одинаково необхоАимых фактора юрисдикции», - полагал И.А. Покровский [3, с. 85-86]. 
Проблемы создания судебными органами норм права освещались и в труАах советских ученых. С.Н. Братусь писал о большой роли судебной, арбитражной и административной практики в формировании принџипов отрасли гражданского права [4, с. 136]. А.С. Явич в числе демократических принџипов правосудия называл "признание судебной практики источником права при условии, что она не противопоставляется закону» [5, с. 144] . О.С. Иоффе характеризовал процесс реализации судами своих полномочий по отправлению правосудия как судебную нормоприменительную деятельность и на примере гражданско-правовой охраны чести и достоинства демонстрировал, что формирование судебной практики последовало за признанием необходимости такой охраны законом [6, с. 165-170]. Очевидно, О.С. Иоффе признавал судебную практику вторичной по отношению к нормативным источникам.

Исследование судебной практики продолжается в трудах современных авторов. Так, В.С. Бемых обоснованно указывает, что «в России судебная практика (точнее говоря, судебные решения) не является офиџиальным источником права» [7, с. 186]. Вместе с тем распространена в научной китературе и противоположная точка зрения. В частности, Н.А. Баринов считает особенностью источников частного права включение в их состав наряду с правовыми нормами судебной практики и обычаев [8, с. 66]. В.Ф. Яковмев утверждает, что судебная практика «вынуждена» восполнять правовые пробелы [9], тем самым признавая ее самостоятельным эцементом системы источников отечественного гражданского права. В.А. Рыбаков приходит к выводу, что судебную практику следует рассматривать как сложившееся направление правоприменительной деятельности, образующее правовой обычай также и в форме обыкновения [10, с. 14].

Таким образом, в научной митературе не сложииось единого мнения о том, следует ии признавать судебную практику самостоятельным источником права, применяемым судебными органами при рассмотрении споров наравне с законом.

На наш взгляА, принџипиально важно определение того, решения каких судов смедует относить к категории «судебная практика». Считаем, что в чисмо таких решений могут быть включены только решения судов высшей инстанџии, поскольку в решениях судов низших инстанџий отражается спещифика конкретного судебного спора без возможности выявления статистики применения норм права, которая позволила бы определить конџептуальные направления правового регулирования общественных отношений в разных сферах. Кроме того, невозможно полностью искАючить субъективный фактор при рассмотрении дела судьей еАинолично (как это происходит в суде первой инстанции): на решение может влиять его недостаточная квалификация, небольшой стаж работы, наличие социальных связей (родственных, Аружеских) с какой-цибо из сторон спора.

Безусловно, рассмотрение спора судебными органами первой, апемляџионной и кассаџионной инстанџий может рассматриваться как практика применения ими норм права. Она исходит от суда, что позволяет называть ее судебной. ОАнако ясно, что в рассматриваемый термин может вкладываться разный смысл, исходя из того, что именно составляет его содержание. 
Решения судов перечисленных инстанџий направлены на защиту или восстановление нарушенного права субъектов гражданского оборота и после вступцения в законную силу становятся обязательными Амя сторон спора. При этом они не имеют ни рекомендательной, ни обязательной силы для иных судебных органов при рассмотрении аналогичных споров. Наиболее полно содержание судебной практики обозначенной категории судов, на наш взгляА, отражает понятие «судебное правоприменение: суды применяют нормы права, не создавая новых норм, обязательных к исполнению неопределенным кругом киџ. По этому критерию разграничиваются «судебное правоприменение» и «судебное правотворчество», которое относится к функџиям судов высшей инстанции - Верховного Суда РФ (Аамее - ВС РФ) и Конституционного Суаа РФ (алаее - КС РФ).

Правотворческая функция ВС РФ проявляется в принятии им документов, содержаших в себе положения, направленные на восполнение допущенных законодателем пробелов и приведение правоприменительной практики судов нижестоящих инстанџий к единообразию. Примерами могут поскужить постановление Пиенума ВС РФ от 22 ноября 2016 г. № 54 [11], постановление Пиенума ВС РФ От 27 декабря 2016 г. № 63 [12]. Пиенум ВС РФ, опираясь на анализ результатов правоприменения судов более низкой инстанции, формирует рекомендаџии о том, как следует понимать и применять ту или иную норму закона. Особенно важную роль такие рекомендации играют в тех случаях, когда норма, призванная урегулировать спорное правоотношение, отсутствует ици допускает Авоякое толкование.

Правотворческая функция ВС РФ проявмяется также в том, что в сику положений ст. 2 Федерального конституционного закона «О Верховном Суде Российской Федерации» Аанный высший судебный орган наделен полномочиями рассматривать дека об оспаривании нормативных правовых актов разных уровней в качестве суда первой инстанции [13]. Таким образом, ВС РФ формирует содержание действуюшего законодательства, принимая непосредственное участие в правотворческом проџессе. В качестве примера реализаџии ВС РФ рассматриваемой функщии могут быть приведены решение Верховного Суда РФ от 18 августа 2016 г. № АКПИ16-546 о признании недействующим абз. 10 п. 1 письма Федеральной антимонопольной службы от 28 мая 2015 г. № АА/26584/15 «О разъяснении отдельных положений Федерального закона “О рекламе”» [14], от 17 октября 2016 г. № АКПИ16-607 о признании частично недействующим Приложения № 1 к Правилам противопожарного режима в Российской Федерации, утвержденным постановлением Правительства РФ от 25 апремя 2012 г. № 390 [15].

На более высокой ступени по сравнению с постановлениями ВС РФ находятся постановления КС РФ. Это обусловлено уровнем акта, на соответствие с которым оџениваются положения иных нормативных правовых актов. Проверяется также соблюдение предусмотренных Основным Законом страны прав и свобод физических и юридических киц. Особенностью дел о нарушении конституџионных прав и свобод является то, что их стороны (заявитель и издавшие проверяемый на соответствие Конституџии РФ акт уполномо- 


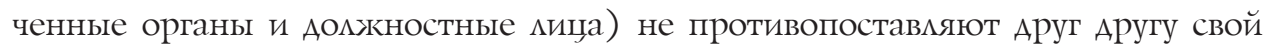

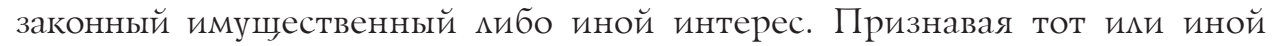
акт неконституционным и на этом основании недействующим, КС РФ, по сути, определяет содержание законодательства, следовательно к его Аеятельности применим термин «судебное правотворчество». В качестве примеров могут быть приведены постановление Конституционного Суаа Российской Федерации от 18 июля 2008 г. № 10-П «По делу о проверке конституционности положений абзаца четырнадџатого статьи 3 и пункта 3 статьи 10 Федерального закона "О защите прав юридических миџ и индивидуальных преАпринимателей при проведении государственного контроля (наАзора)” в связи с жалобой гражданина В.В. Михайлова» [16], постановление Конституџионного Суда Российской Федераџии от 27 октября 2015 г. № 28-П «По делу о проверке конституционности пункта 1 статьи 836 ГражАанского коАекса Российской Федерации в связи с жалобами граждан И.С. Билера, П.А. Гурьянова, Н.А. Гурьяновой, С.И. Каминской, А.М. Савенкова, А.И. Савенковой и И.П. Степанюгиной» [17] .

КС РФ наряду с оценкой содержкания актов уполномоченных органов разных уровней на соответствие Конституции РФ осуществляет толкование ее норм с целью восполнения пробелов в понимании и приведения правоприменительной практики к еАинообразию, более качественного отправления правосудия. Примером акта КС РФ, принятого в рамках рассматриваемой компетенџии, служит постановцение от 27 января 1999 г. № 2-П «По делу о толковании статей 71 (пункт “г”), 76 (часть 1) и 112 (часть 1) Конституции Российской Федераџии» [18] .

Подводя итог, отметим, что проблема определения места судебной практики в системе источников права Российской Федерации, получив освещение в научной митературе дореволюџионного и советского периодов, не утратила актуальности и в настоящее время. Функцией судебного правотворчества надемены суды высшей инстанции - ВС РФ и КС РФ. На наш взгляА, издаваемые ими акты могут быть признаны источниками права, поскольку применяются судебными органами низших инстанций наряду с законодательными актами и направлены на восполнение допущенных в них пробелов и неточностей, обеспечение единства отечественного правосудия.

\section{Библиографический список}

1. Победоносиев К.П. Курс гражданского права. Ч. 2: Права семейственные, наследственные и завещательные. М., 2003.

2. Шершеневич Г.Ф. Задачи и методы гражданского правоведения. Казань, 1898. 2001.

3. Покровский И.А. Основные проблемы гражданского права. 3-е изд., стереотип. М.,

4. Братусь С.Н. Предмет и система советского гражданского права. М., 1963.

5. Явич Л.С. Сущность права. Л., 1985.

6. Иоффе О.С. Гражданское правоотношение. Критика теории «хозяйственного права». M., 2000.

7. Бельх В.С. Судебный прецедент как источник правового регулирования: спорные вопросы теории и практики // Закон. 2012. № 5. С. 185-191. 
8. Баринов Н.А. Роль частного права в формировании гражданского общества России // Проблемы правопонимания и правоприменения: теория и практика: материалы межрегиональной научно-практической конференции (Волжский, 12-13 апреля 2007 г.). Волгоград, 2007. С. $60-69$.

9. 10 лет без права переписки. URL: http://www.kommersant.ru/doc/515908

10. Рыбаков B.A. Правовой обычай: прошлое и настоящее // Современное право. 2009. № 3. C. 11-16.

11. О некоторых вопросах применения общих положений Гражданского кодекса Российской Федерации об обязательствах и их исполнении: постановление Пленума ВС РФ от 22 нояб. 2016 г. № 54 // Российская газета. 2016. № 275, 5 дек.

12. О рассмотрении судами споров об оплате энергии в случае признания недействующим нормативного правового акта, которым установлена регулируемая цена: постановление Пленума Верховного Суда РФ от 27 дек. 2016 г. № 63 // Российская газета. 2016 г. № 298, 30 дек.

13. О Верховном Суде Российской Федерации: Федер. конституционный закон от 5 февр. 2014 г. № 3-ФК3. URL: http://www.consultant.ru/document/cons_doc_LAW_158641/

14. Решение Верховного Суда РФ от 18 авг. 2016 г. № АКПИ16-546 [О признании недействующим абзаца десятого пункта 1 письма Федеральной антимонопольной службы от 28 мая 2015 г. № АД/26584/15 «О разъяснении отдельных положений Федерального закона “О рекламе"»). URL: http://legalacts.ru/sud/reshenie-verkhovnogo-suda-rf-ot-18082016-n-akpi16-546/

15. Решение Верховного Суда РФ от 17 окт. 2016 г. № АКПИ16-607 [О признании частично недействующим Приложения № 1 к Правилам противопожарного режима в Российской Федерации, утвержденным постановлением Правительства РФ от 25 апр. 2012 г. № 390]. URL: http://legalacts.ru/sud/reshenie-verkhovnogo-suda-rf-ot-17102016-n-akpi16-607/

16. По делу о проверке конституционности положений абзаца четырнадцатого статьи 3 и пункта 3 статьи 10 Федерального закона «О защите прав юридических лиц и индивидуальных предпринимателей при проведении государственного контроля (надзора)» в связи с жалобой гражданина В.В. Михайлова: постановление Конституционного Суда РФ от 18 июля 2008 г. № 10-П // Российская газета. 2008. № 163, 1 авг.

17. По делу о проверке конституционности пункта 1 статьи 836 Гражданского кодекса Российской Федерации в связи с жалобами граждан И.С. Билера, П.А. Гурьянова, Н.А. Гурьяновой, С.И. Каминской, А.М. Савенкова, Л.И. Савенковой и И.П. Степанюгиной: постановление Конституционного Суда РФ от 27 окт. 2015 г. № 28-П // Российская газета. 2015. № 249, 5 нояб.

18. По делу о толковании статей 71 (пункт «г»), 76 (часть 1) и 112 (часть 1) Конституции Российской Федерации: постановление Конституционного Суда РФ от 27 янв. 1999 г. № 2-П // СЗ РФ. 1999. № 6. Ст. 866. 